\title{
TITLE REGISTRATION AND LAND LAW REFORM: A REPLY
}

\author{
Myres S. McDojgaL*
}

W

RITING under the somewhat question-begging title of "The Resurrection of Title Registration" in the April, I940, issue of this Review, I Professor Percy Bordwell, dean of American property law teachers, ${ }^{2}$ seeks to condemn, albeit in a half-hearted and ambiguous way, that method of keeping the public books about land which has popularly come to be known as the Torrens System. Largely an answer to certain uncompromising criticisms of Professor Richard B. Powell's earlier condemnation of that system in his Registration of the Title to Land in the State of New York, ${ }^{3}$ Professor Bordwell's article is so temperate in tone and so speciously reasonable, with its generous concessions, that a reader unfamiliar with the problem may miss its paradoxical quality and the utter inconclusiveness of its argument.

The burden of Professor Bordwell's complaint is several-fold. ${ }^{4}$ The advocates of title registration, he asserts, have "largely assumed its manifest superiority over prevalent systems of recording." To explain away the

* Professor of Law, Yale University.

× Bordwell, The Resurrection of Registration of Title, 7 Univ. Chi. L. Rev. 470 (r940), hereinafter cited simply as Bordwell.

2 Perhaps I should make it explicit that by the argumentative tone of this reply I intend no disrespect for Professor Bordwell. As a relative newcomer to the property field, I have found his writings on other problems most helpful. What I am trying to show here is that, despite his shying away from the word "Torrens," he is really on the side of the angels on this problem.

3 Powell, Registration of the Title to Land in the State of New York (1938). The criticisms Professor Bordwell cites are McDougal and Brabner-Smith, Land Title Transfer: A Regression, 48 Yale L.J. I125 (I939), and Fairchild and Springer, A Criticism of Powell's Book, 24 Corn. L.Q. 557 (1939). To these could have been added the reviews by Professor Edward S. Bade in 23 Minn. L. Rev. 874 (r939) and Professor William F. Walsh in I6 N.Y.U.L.Q. Rev. 5 Io (1939).

4 This paragraph and the one following offer a free-handed summary of the entire article; page citations to the various quotations are omitted.

Throughout this discussion, for sake of brevity, "registration" and "recordation" are used as if they referred to opposing absolutes; elsewhere a colleague and I have decried this sharp dichotomy and sought to show that the "logical outcome of any thoroughgoing reform" of the recording system must be registration. McDougal and Brabner-Smith, op. cit. supra note 3, at Ir49. Professor Bordwell approves this effort to get away from the prejudice of "names" which "too easily run into conceptualism." Bordwell, 472 n. 6 . The context here should make my meaning clear. 
"outstanding fact" of "the ineffectiveness," "the failure," of voluntary registration in this country and England they have "harped" upon the "self-interest" of solicitors and abstracters and title insurance companies and have adopted a "Satanic interpretation of history" which "does not get us anywhere." Experience in the Anglo-American countries demonstrates that registration must be made compulsory to amount to anything. But why make it compulsory? "Why all this fuss about title registration?" There has been "no such conspicuous failure" of the recording system or of title insurance as to discredit either. Title registration cannot make land "liquid" and "as easily transferable as a ship or a share of stock or an automobile"; such extravagant hopes are but a reflection of the fight for "free trade in land in England." "No millennium will be wrought by a register of title." Registration, being unsuitable for multiple interests, might, however-strange as it may seem-imperil our historic law of estates and future interests; the scrapping of such interests was a "by-product" (also the "most outstanding feat") of the struggle for registration in England. "The important thing to bear in mind is that the logic of registration of title is a revolution in our land law." Finally, we have one "system of public transfers" already; why "supplant" it with another which may raise constitutional and personnel difficulties and produce a lack of "coherence and uniformity" in the common law "throughout the country"? The Torrens System is a "foreign" system. "Regardless of the conclusiveness of the certificate, of the desirability of cutting off stale claims and of the modern tendency to look to the state," the case for it is not made out.

So much for the argument; now for amplification of the paradox. It extends beyond the weird millennium-revolution inconsistency on the reforming powers of registration, beyond the final, for-the-sake-of-the-argument, concessions about the conclusiveness of the registration certificate and the desirability of cutting off stale claims, and beyond a passing reference to certain "more substantial arguments"s for registration: "its relative cheapness in the long run, the greater rapidity of transfer, and the saving of lost motion." The fact is that Professor Bordwell strongly favors title registration - or at least all of the important administrative features of such a system. Before "anything more revolutionary" is tried, he urges, the governmental units keeping the public books about land should establish an "adequate" official index-that is, a tract, as opposed to a grantorgrantee alphabetical index. Furthermore, the "arguments" for some "more adequate method of trying title to land," "a comprehensive action," are "very strong." What more does title registration involve?

s More substantial than the argument for "liquidity." 
Precious little of any difficulty or danger, as we shall seek to show. Professor Bordwell, however, finds it a "far cry" to the Torrens System. What he seems to fear is some bugaboo of "a determination of title," an unskilled administrative "passing on the marketability of the title."

For proper appraisal of Professor Bordwell's position, and as a prelude to a more detailed examination of his arguments and concessions, let us look for a moment in barest outline at the relevant portions of our contemporary American institution of land transfer.

To a foreign anthropologist land transfer in the United States would probably look, as one of my former students forcefully put it, much like an aboriginal, ritualistic clambake. Like most other objects of "property," land is transferred by symbols, pieces of paper; but, unlike many of the other symbols, these particular symbols do not pass freely from hand to hand-their circulation is accompanied by much dilatory, costly, and extra-necessitous behavior of wise men. Transfer is normally effected by a double-barrelled ceremony requiring both a "contract" and a "deed" and culminating in "recordation" of at least the latter. Why the two symbols of contract and deed? Why a period of time between "agreement" and final "transfer"? Largely because of "title" difficulties, of "insecurities" in the public recording system. ${ }^{6}$ The vendor must have opportunity to prove and the vendee to determine that the vendor has what he says he has. This requires either an elaborate search of the alphabetically-indexed public records against every former owner of the land, beginning with a good "root" of title at a date so distant that adverse possession must have cured all prior defects, or else resort to the owners of some private title plant who have kept all the entries in the public records up to date with a better index. ${ }^{7}$ To the danger that something may be missed in this search must

${ }^{6}$ Other difficulties-e.g., the necessity of making financial arrangements-may of course cause delay in closing; but the "title" difficulties, largely unique to land transfer, have undoubtedly been the major factor in molding our contemporary, complex institutional procedure.

7 For elaboration and citations see McDougal and Brabner-Smith, op. cit. supra note 3 , at II27. The first three chapters of Patton on Titles (1938) offer a relatively complete picture of the procedure and dangers so impressionistically sketched here.

Professor Bordwell suggests that the waste motion under the present system is much exaggerated. He points to the use of abstracts and to the tract-indexed private plants. The abstract and title companies must, however, keep their books up to date by constant examination and transcription of the public records; it is even not unknown for them to be housed in the public buildings for their greater convenience in such work. Furthermore, under the present system there is no assurance that any saving in labor effected by private monopoly will be passed on to the consumer in lower costs. Finally, abstracters assume liability to a limited number of people only and title insurance is generally non-assignable; no private monopoly built on recordation does, or can, offer as registration does a product "repeatedly available after one principal fee." Cf. Viele, The Problem of Land Titles, 44 Pol. Sci. Q. 42x, 434 (I929). 
be added the doctrine of caveat emptor and the fact that at the present time a multitude of interests are not even required to be evidenced in the public records. ${ }^{8}$ It is, hence, not unnatural that on the closing date, when the deed is to be delivered and the price paid or secured, a dispute not infrequently arises as to what the vendor actually has; it is notoriously a poor lawyer who cannot find something wrong, or apparently wrong, with a title as old as most titles are in this country. ${ }^{9}$ Such a dispute may force the vendor to bring suit either to quiet his title against the allegedly interested parties or to get a court to declare, as against the vendee, that his title is "marketable," despite possible defects. .0 Eventually accepting or being forced to accept the proffered deed and land, the vendee still has no assurance that he will be able to keep the land or even be reimbursed if he loses the land. When some ghostly defect does materialize and a claimant "prior" to his vendor takes the land, what is his recourse? He can go back on his vendor only if he extracted a "warranty" deed and his vendor is still "available, solvent, and unable to escape through some of the loopholes in the highly technical judicial doctrines about covenants." ${ }^{\prime \prime x}$ He can go back on his lawyer or his abstracter only if he can prove "negligence." $\mathrm{He}$ can recover from a title insurance company only if he has made the extra payment for such protection and probably only if he has obtained a policy, rara avis, which does something more than guarantee a careful

${ }^{8} \mathrm{McDougal}$ and Brabner-Smith, op. cit. supra note 3 , list nineteen categories of such interests. See also Patton, op. cit. supra note 7 .

Recent statements of local problems indicate little, if any, decrease in either wasted motion or the frailties of the record. McCutcheon, Examination of Titles-The Lawyers Problem, I3 Idaho State Bar Proceedings 29 (1937); Forbes, The Title Examiner's Burden, 24 Iowa I. Rev. (5 Bar Sec. 72) (1939); Title Search in Virginia, 26 Va. L. Rev. 385 (1940); Real Estate Title Standards, I2 Conn. B. J. roo (1938); Winn, The Examination of Titles in Kentucky, 27 Ky.L.J. I94 (r939); Hendricks, Defects in Title to Real Estate and Remedies, 20 Marquette L. Rev. II5 (I936). A dramatic, if somewhat older, account of title insecurities appears in Crocker, The History of a Title, 22 Minn. L. Rev. I29 (1937), reprinted from ro Am. L. Rev. 60 (1875).

9 The fariciful defects trouble has become so bad that title lawyers are beginning to try to outlaw it by gentlemen's agreements. Lyman, Distinguishing Apparent and Real Title Defects: Standardizing Opinions, Proceedings, A.B.A. Section on Real Property, Probate and Trust Law (r939); Real Estate Title Standards, I2 Conn. B.J. Ioo (1938). By accepting certain "standards" for distinguishing between "real" and "apparent" defects, title examiners promise not to raise certain defects. This is, of course, mere whitewash for the cancers in the public records; it probes none of the roots of the trouble. With such ineffective, costly, and cumbersome efforts, contrast registration with its clean excision of the defects in the records and of most of the lawyer's tribulations.

so The court declares, in effect, not that the title is "good," merely that it is highly improbable that any of the conceivable defects will ever materialize.

Ix McDougal and Brabner-Smith, op. cit. supra note 3, at Ir29.

12 Gage, Land Title Assuring Agencies in the United States 50, 56 (r937). 
search by the abstracter. ${ }^{13}$ Such are but minimum indications of the difficulties and absurdities of the system in which Professor Bordwell finds no "conspicuous breakdown."

To assume the merits of an alternative system-thoroughly tried over a long period of time in Europe, England, the British Dominions, and several of our own states ${ }^{\text {I }}$ - which offers an expeditious mode of getting rid of stale claims, which by its tract index and constant posting of the books eliminates the tedious, costly search and the necessity of paying monopoly prices, which by making the records for all practical purposes conclusive insures that the bona fide purchaser will really get the land, which at negligible cost offers adequate recourse to anybody injured by the operation of the system, and which greatly shortens and cheapens the whole process of land transfer, would seem to be no great intellectual crime. ${ }^{\text {Is }}$ Such broad claims for title registration are not in fact "assumed"; they are not the vain, visionary hopes of Utopian reformers, but are based on the actual results of the practical operation of the system in places as nearby as Massachusetts, Tllinois, and Minnesota. ${ }^{16}$ Yet Professor Bordwell relies

${ }^{23}$ Ibid., at 90 et seq.; Walsh, op. cit. supra note $3:$ "Lawyers know that a policy as such is of little value as insurance; its principal value is that it represents a thorough search which is guaranteed." Glib comparisons between title insurance and registration sometimes ignore the fact, well-known professionally, that "title insurance" is little more than a financially responsible system for pointing out what the defects are, not for insuring against them. The insurance seldom adds very much to the protection afforded by the ordinary doctrines of negligence. What is needed for cheap and adequate protection of purchasers is obviously not so much an efficient bearer of the risk of carelessness in the discovery of defects as a removal of the defects and hence of the risk and cost and trouble of guarding against them.

I4 Powell, op. cit. supra note 3 , passim.

xs For detail see Patton and Patton, Manual of Torrens Procedure (x936); Fairchild and Springer, op. cit. supra note $3 ; \mathrm{McD}$ ougal and Brabner-Smith, op. cit. supra note 3 . Note the differences in the analyses of the costs of initial registration of Professor Powell and his reviewers, and the generally conceded low cost of subsequent transfers.

${ }^{16}$ So much can be gleaned by a careful reading of even Professor Powell's book. See Supplements E, F, and G, Powell, op. cit. supra note 3 . Note especially Richard W. Hale, Torrens System Title Registration Proves Success in Massachusetts, Nat'l Real Estate J. (May, 1939), and letter in 26 A.B.A.J. 369 (I940); Bade, op. cit. supra note 3 ; Patton and Patton, op. cit. supra note 15 . Typical of the tenor of a large number of informal communications which the writer has received from a variety of sources are the following paragraphs by a Boston attorney:

"So far as local practice in Massachusetts is concerned, the highest compliment that can be paid to our system of registration of titles is the fact that attorneys for lenders on real estate are requiring all questionable titles to be taken to the Land Court for registration. I know of no attorney who questions in any way the finality of a Land Court adjudication via registration of title.

"Even so far as the economics of the situation are concerned, you are perfectly right in stating that the present method of examination and re-examination of titles is an uneconomic process, and that lawyers engaged in such practice may readily shift their efforts to the registration 
heavily upon "experience" in this country and England to discredit registration. His error is a simple one: it lies in failing to make a distinction between (I) the preliminary difficulties of getting a registration system adopted and in actual use, and (2) the operation of such a system after it is in use. The only thing that "experience" in this country or England shows, beyond the beneficent results of actual operation indicated above, is that a voluntary system with a costly initial registration (i.e., a "lawsuit"), and without adequate provisions for transition from the old to the new, cannot hope quickly to overcome public ignorance and inertia and professional opposition. There is, however, no insuperable reason why a simple change in the keeping of the public books about a piece of land should have to be initiated by an expensive action to quiet title, ${ }^{17}$ or why a voluntary system should not be given the small public subsidy which would enable it to compete with interests vested in the chaos of the recording system, ${ }^{\mathrm{I}}$ or even why registration should not be made compulsory with transition provisions-requiring registration only on any new sale or mortgage when the title must be searched anyway - which would reduce the strain on public

of titles, and thus in the course of time find similar revenue for such income as might be lost through a shift from the present system.

"When all is said and done, there is no argument or series of arguments that can alter the fact that a title which has been registered is good against the whole world, and renders immediately marketable (so far as title is concerned) all properties so registered. As far as efficiency of the system is concerned the Land Court employees are all devoted to their work, efficient, helpful and extremely well-informed.

"In practice, where a registered title is involved, the transaction of mortgage or sale is hardly ever held up more than an hour or two on account of examination of title, whereas, as to unregistered titles, even the simplest of titles requires a day to a week for examination, with an average of two or three days.

"There is very little doubt as to the sources of opposition to land title registration or as to the reasons therefor. However, the title insurance companies and their attorneys are fighting a losing battle because the 'streamlining' of land titles via registration would seem to be inevitable."

${ }^{x 7}$ For the lawsuit could be substituted a short statute of limitations and the interim registration of a mere "possessory" title. A Comparison of Land and Motor Vehicle Registration, 48 Yale L.J. I 238 (I939). Such an expedient has been tried in England, and its working indicates, as Professor Bordwell says, "that courts have been too fussy about marketable title." Bordwell, 478 .

${ }^{18}$ Professor Bordwell objects to public subsidy as a mode of encouraging voluntary registration, preferring instead compulsory registration. Bordwell, 482. It should be remembered that any governmental service must cost something; the important thing is what the taxpayer gets in return. Does it cost the public nothing to maintain title lawyers, companies, and plants? What of the mounting costs of our inefficient public "recordation" plants and of the possible added expense of adequate public supervision of title insurance? Costs to the individual, taxpayer, or purchaser must be measured in the broader frame of reference of the whole social problem. 
personnel and private pocketbook. ${ }^{\text {I9 }}$ Surely Professor Bordwell knows that it is not any proved demerit of registration which has precluded its wide popular acceptance in this country. It is, of course, easy to take the frequent castigations of title lawyers and companies, to puff them at a high level of abstraction into a "Satanic interpretation of history," and then to ridicule that interpretation. It is quite another thing to establish relative demerits of title registration, as compared with recording, and to get rid of the well-known, tangible, and bitter professional opposition to registration. ${ }^{20}$

The next charge, to fortify the argument that title registration should not be made compulsory, is that title registration cannot, as the free traders in England hoped, make land "liquid" and, hence, will work no millennium. It is true, as Professor Bordwell alleges, that registration is not a new idea. It is much older in many places than the free trade movement in England.2x Professor Bordwell himself has elsewhere found its germs in the copyhold register. ${ }^{22}$ With some little imagination it might even be traced back to the bookland of the Saxons. ${ }^{23}$ More important by far, however, than ambiguous "origins" are contemporary social consequences. Let us see if we cannot without too great strain place this vexed problem in its proper social perspective.

I9 Despite his later vague reference to constitutional difficulties, Professor Bordwell rightly finds no constitutional difficulty in such proposed reform. "But can there be any serious doubt," he asks, "that legislatures can change the method of land transfer if they wish to? To ask the question is to answer it." Cf. A Comparison of Land and Motor Vehicle Registration, 48 Yale L.J. I 238 (1939). What can General MacChesney mean when he writes that the "law" is against registration? MacChesney, Review of the book Registration to the Title to Land in the State of New York, 26 A.B.A.J. 158 (I940).

${ }^{20} \mathrm{~A}$ selected list of citations to secondary documentation of this opposition appears in McDougal and Brabner-Smith, op. cit. supra note 3, at II47 n. I25. Cf. also Bordwell, Registration of Title to Land, I2 Iowa L. Rev. II4, I26 (I927).

Professor Bordwell writes (Bordwell, 470): "There is no more insidious self-interest than that of a government department desiring to expand." Insidious? How so? Such "self-interest" must have as its dominant motivation, and public justification, not private pecuniary profit but public service, and it is subject, in a democratic government, to public scrutiny, supervision and control. The mainsprings and controls of the private entrepreneur and of the public servant are not the same; not because they are different men, but because they work in a different "institutional" context. Furthermore, Professor Bordwell is here again flaying a ghost. By his own major argument-the ineffectiveness of voluntary systems-the will to power of registration clerks has been not so much satanic as pathetic.

2x Bordwell, Land Transfer, 9 Encyc. Soc. Sci. I27, I30 (1937); Powell, op. cit. supra note 3. It is a little strange to find registration belittled because it is not a novel idea; usually the dialectics cut the other way.

${ }_{22}$ Op. cit. supra note 2I, at I29. Cf. Walker, Genesis of Land Registration in England, 55 L.Q. Rev. 547 (1939).

${ }^{23}$ I Vinogradoff, Collected Papers 99 (I928). 
"The fundamental purpose back of all recording" is, Professor Aigler has aptly written, ${ }^{24}$ "the provision of data available to the public by which the prospective purchaser may, measurably at least, determine the safety of dealing with the prospective vendor." We have seen how poorly, at what cost, and how slowly the recording system provides this information and how expeditiously and cheaply registration supplies it. Still a prospective purchaser wants something more than mere information; he wants protection, security in his purchase, his plans, his improvementsand that registration alone can offer. ${ }^{25}$ Such information and protection would seem indeed to be the barest minima of required encouragement to "free enterprise" in buying and selling land; freest alienability must demand the removal of every adventitious and extra-necessitous restraint and psychological deterrent. ${ }^{26}$ Yet does it necessarily follow that such information and protection are not, as Professor Bordwell's attempt to tie registration to the defunct "free trade" movement would seem to imply, equally the barest minima which must be provided by and for a society about to embark upon rational programs of community planning, housing and resource conservation? Per contra, a fortiori. For the effective prosecution of such programs even more adequate information, better protection, and lowered costs would seem to be essential, and recent experience of a wide variety of planning agencies in this country confirms the inference. ${ }^{27}$ Drainage basin authorities have, for example, not infrequently been forced to pay more than the cost of the land to get the title to a right of way cleared; housing authorities have been hampered and delayed in their demolition and reconstruction programs and often forced to costly condemnation proceedings simply to clear up title; effective administration of all of the techniques of community planning-zoning, subdivision control, street control, public improvements, municipal ownership-has been found to require quick and cheap ascertainment of the interested parties. ${ }^{28}$ Hence, whatever the social philosophy-whether "free enter-

${ }_{24}$ Aigler, The Operation of the Recording Acts, 22 Mich. I. Rev. 405 (I924).

${ }^{25}$ Recall the limitations of title insurance, indicated supra note 13 , and that it never insures that the purchaser will actually get the land; at its best, it offers only financially responsible recourse in case of the loss of the land. Furthermore, the "recourse" it offers may not cover any increment in value or improvements.

${ }^{26}$ Dicey, The Paradox of the Land Law, 2I L.Q. Rev. 221 (I905).

${ }^{27}$ A private purchaser who discovers something questionable about the title to a piece of land can look elsewhere for other land; a government agency, on the other hand, which has embarked on a large-scale housing or drainage basin program must get title to every parcel of land in the designated area.

${ }^{28}$ These generalizations are based largely on letters from and conversations with attorneys. An adequate study of the experience of a variety of governmental agencies in land title acquisi- 
prise" or "collective planning" or some one of the infinite combinations of these two polar abstractions ${ }^{29}$-title registration would seem to be an indispensable element in any rational program of land utilization.

It can be conceded, without weakening our argument, that registration alone will not make land completely "liquid," an entirely reliable and quickly realizable emergency asset; few objects of property do have that elusive quality. Yet why should we passively continue to tolerate a business cycle which is longer and much more severe with respect to land than with respect to any other commodity? Powers for alleviation are ready to hand and have been thoroughly, if sporadically and singly, tested in isolated communities. What is needed is an integrated and comprehensive program of land law reform. Registration alone can accomplish the removal of the unnecessary and adventitious restraints on alienation which have been described above and can serve the function of supplying quick and cheap title information and security to planners as well as purchasers. So much and no more would be a solid gain for liquidity! But an

tion remains to be made. Note the beginnings of such a study in Russell and Bridewell, Systems of Land Title Examination: An Appraisal, I4 J. of Land \& Pub. Util. Econ. I33 (I938), with conclusions favorable to registration. Cf. the testimony of Walker, Assistant General Counsel, HOLC, Investigation of Concentration of Economic Power, Hearings before the TNEC, pt. Ix, Construction Industry, at 5168. Popular literature on housing and community planning offers confirmation. "Surprising as it may seem, experience has shown that the failure to assemble large tracts of land by purchase alone is due as frequently to the need for clearing doubtful titles as it is to the demand of 'hold-outs' for exorbitant prices." Walker, Urban Blight and Slums I75 (I938). On the title problems in a demolition program, see 2 Ford, Slums and Housing 608 (r936). Heydecker, Public Ownership and Control of Urban and Suburban Land, 26 Nat'l Municipal Rev. 56I (I937), discussing a program of general municipal land planning, calls for: "Simplification and strengthening of present laws for registering land titles in accordance with the well established principles of the Torrens System of title registration already used in several states." Cf. the comparison of land and securities in Monchow, California's Subdivision Control Sustained, I5 J. of Land \& Pub. Util. Econ. 97 (r939). Witness the dificulties of the FHA in Matter of City of New York (I57th St., Queens), 257 App. Div. 5 II, I3 N.Y.S. (2d) 587 (1939), noted in 40 Col. L. Rev. I45 (I940).

29 Here once more simple dichotomy is false to fact. No modern economy wholly excludes either free enterprise or collective planning; in varying proportions and combinations the two work side by side, if not with the greatest of ease, at least without possibility of dissolution. Compare the five types of economic organization which Chamberlain, American Stakes 287 (I940), finds working under the "dispensation" of "finance capitalism" in this country. The Dicey article, op. cit. supra note 26, which Professor Bordwell cites (Bordwell, 472 n. 7) as an "illuminating account" of the relation of registration to the "free trade" movement, is guilty of too facile an opposition of "free transfer" and "nationalisation." Collective planning to encourage free enterprise in land transactions may be, not a philosophical nightmare, but enlightened public policy. High, polar abstractions must not be allowed to conceal the problems and complexities, the similarities and dissimilarities, of actual underlying social organizations. Kruse, The Right of Property 8 et seq. (I939). 
effective attack on blight and speculation and all of their attendant evils ${ }^{30}$ calls for much more: it calls for an integrated exercise of all the planning, credit, and tax powers which our municipal, state, and national governments possess..$^{3 x}$ Such a program could, as some few people are coming to realize, do much to remove land from the chaos of our contemporary economy, and so to provide more of the necessities of health and "the good life" to the low-income half of our population.

By what interpretation of history, one wonders, is a mere change in the keeping of the public books about land likely to result in-dreadful thought-a scrapping of our historic law of estates? It comes perilously close to the old tail-wagging-the-dog theory. ${ }^{32}$ Why should a register, a tract index, be any more "unsuitable for the multiple common law estates" than an alphabetical index? How, furthermore, does Professor

${ }^{30}$ This is not the context, of course, in which to expand upon our heritage of fantastically inflated land values, slums, blighted neighborhoods, and still-born "dormitory suburbs," upon which our institutional lenders are dependent for solvency; or upon our multiplicitous, overlapping municipal governments for the supplying of indispensable public services which are now being underwritten to the extent of billions of dollars by the Federal Government; or upon the more than $10,000,000$ families-over $40,000,000$ people-still housed in dwellings unfit for human habitation, substandard by any definition of substandard; or upon the 40,000 new farm tenants being added annually to an already impoverished, disease-ridden peasantry; or upon the continuous wasteful and destructive exploitation of our land and other natural resources. The reader who requires a reminder or initiation can find an excellent, popular presentation in Abrams, Revolution in Land (1939).

${ }^{3 x}$ This is in substance, though he does not adequately point it up, the plea of Abrams, op. cit. supra note 30 . A suggestive outline of part of the program appears in Heydecker, op. cit. supra note 28. See also National Resources Committee, Our Cities: Their Role in the National Economy, pt. 3 (I937).

Professor Bordwell finds an inconsistency between registration and the use of the tax power for policy purposes. The advocates of registration, he writes, are certainly "at the opposite pole from the advocates of that other panacea, the Single Tax, who would deny not only all resemblance between chattels and land but also the private ownership of land." One of the major battle-cries of the modern Georgians is, however, that the fuller taxation of land-rent will encourage and stimulate, not only a moribund, monopolistic construction industry, but also the private use and exploitation of land, as opposed to socialization-whatever the latter may mean. Geiger, The Theory of the Land Question 186 et seq (1936); Buttenheim, Unwise Taxation as a Burden on Housing, 48 Yale L.J. 240 (I938). By reducing the price of land, they hope to make it more freely alienable and hence more easily utilized. The antithesis which Professor Bordwell draws is a false one. "Resemblance" depends upon the purpose of the comparison. When Georgians say that land, unlike "chattels," is not the product of man's labor, they are making no statement about the mechanics of transferring either. Simplification of the mechanics of land transfer and the use of the tax power to lower land prices are far from "opposite poles"; they are in fact, as indicated above, complementary and equally essential elements in an integrated, comprehensive program of land law reform.

${ }^{32}$ Note also at least a faint, melancholic resemblance to the what-are-we-coming-to theory. Don't give the reformers an inch, however reasonable the inch; they might take a mile! 
Bordwell square his fears for the "common law" estates with his later approval of the tract index? The private title companies, who presumably cherish our "wonderful calculus" of interests, have not yet been heard to complain about the inadequacies of such an index. In fact, it would seem that the better and more efficiently the public books are kept the easier and more adequate would be the protection which could be afforded complex future interests. ${ }^{33}$ The "complexity" of the interests which are to be allowed in land is one problem, governed by its own peculiar policy considerations. The way the books are to be kept is a different problemlargely a technological problem ${ }^{34}$-and hence governed by different policy considerations. The "logic" of registration has nothing to do with a revolution in the "law of estates"; the revolution which it should accompany is, as indicated above, in the law of land utilization. The contemporary overlap between the law of estates and the law of land utilization is practically nil and should be less. The only overlap is in the rare case when a life tenant (or trustee, to add the "equitable" interests) has no granted, judicial, or statutory power of sale ${ }^{35}$ or when a life tenant (no need to add the trustee here) gets caught in the meshes of a law of "waste" inherited from medieval England and cannot make improvements. ${ }^{36}$ As Professor Bordwell says elsewhere in his argument, "In the United States land is freely alienable." 37 The law of "estates"-even when expanded to take in "future interests" generally-does not today in this country de-

${ }_{33}$ "Registration can be made in the name of the life tenant or owner of the possessory estate and memorials entered upon the register and certificate indicating that the land is held subject to certain future interests which an intending purchaser can ascertain by looking at the filed documents creating such interests." McDougal and Brabner-Smith, op. cit. supra note 3 , at II38.

34 Title lawyers who resist improvements in the methods of keeping the public books about land do not have the justifications of labor leaders who resist and sabotage other technological improvements. A more apt analogy might be found in patent suppression.

35 On the continuous shrinkage of this overlap, see Recent Statutes, 37 Col. L. Rev. I238 (I937), and New York Law Revision Commission Report 355 (1935).

${ }^{36}$ The notorious Brokaw v. Fairchild, I35 Misc. 70, 237 N.Y. Supp. 6 (I929); 23I App. Div. 704, 245 N.Y. Supp. 402 (I930); 256 N.Y. 670, I77 N.E. I86 (I93I), has received statutory repudiation in New York and is not likely to be followed by reasonably enlightened courts elsewhere. Recent Statutes, 38 Col. L. Rev. 532 (I938); New York Law Revision Commission Report 389 (1935); Aigler, Comment, 30 Mich. L. Rev. 78 (1932).

${ }^{37}$ Bordwell, 478. If a growing use of possibilities of reverter and rights of entry should ever raise any practical barriers to alienability or effective utilization, a remedy could be found. There are rumblings already: Leach, Cases and Materials on Future Interests 20, $50 \mathrm{n} .25$ (2d ed. 1940); Ferrier, Determinable Fees and Fees upon Condition Subsequent in California, 24 Calif. L. Rev. $5^{12}$ (1936); Legislation, [I940] Wis. L. Rev. I2I. In any event-such interests offer no great difficulty for the mechanics of registration. 
termine land utilization; its chief functions are to make possible provision for incompetent dependents and to serve as a vehicle for tax avoidance. Furthermore, the complexity of that law has been greatly exaggerated. The tenuous distinctions between the various "categories" of "interests," the differences between the treatment of land and personalty, and the differences between "legal" and "equitable" are much less important than is commonly thought, and it probably would be no great tragedy if they completely disappeared..$^{8}$ Professor Bordwell, if he is right in his dire prophecies, has made another strong argument for registration.

The repudiation of registration because we have one "public" system already makes too much an absolute of "public." It would freeze us in an oxcart in a day of streamlined Zephyrs. One might as well argue that a bank because it has already one system of keeping books, however inadequate, should make no efforts to improve or change that system. Obviously, however, this cannot be what Professor Bordwell means. He makes very definite suggestions for the improvement of our existing "public" (i.e., the recording) system. He proposes not only the tract indexes but also a new and improved action to quiet title. Surely he could have no objectionand the whole tenor of his argument suggests that he would have no objection once the public books were put in reasonable order-to making them more conclusive on sleeping interests-or, more exactly, putative

${ }^{38}$ Professor Bordwell might agree. Review of the Restatement of the Law of Property, $5^{\mathrm{I}}$ Harv. L. Rev. ${ }_{5} 65$ (1938), and Review of the book Cases and Materials on the Law of Future Interests, 2I Iowa L. Rev. I60 (r935). On the other hand, he might not. Bordwell, The Common Law Scheme of Estates, r8 Iowa L. Rev. 425, 426 (I933). In the article presently under review he questions whether "the common law doctrine of estates is an anachronism" and wonders what we would do for "theory" about future interests in chattels without it. "Were the law of estates and future interests abolished, we should be obliged to start all over again with ideas based on the crude notions of property in chattels, or with something like the civil law notion of dominium, or to throw the whole into equity as has been done in England. No one of these three courses seems desirable." Bordwell, 477. This both overestimates the importance of the existing "estates" categories and underestimates our powers of creative generalization from our own recent American experience. Most of the differences between the historic categories are either praeposterous, i.e., completely in terms of legal consequences, or else verbal, such as the difference between "so long as" and "but if." Little or no policy justification can be found for making any difference out of any of these differences. It is not impossible to conceive of one category of "future interest" which ignores them; in fact, we may already be approaching such a devoutly to-be-wished-for consummation without knowing it. Justice Frankfurter's opinion about "unwitty diversities" in Helvering v. Hallock, 309 U.S. IO6 (1939), despite its omissions from the new edition of Professor Leach's casebook, op. cit. supra note 37 , is more than a straw in the wind; it is itself a lusty gale which could blow through problems other than taxation. Likewise, the time may come when the differences between "law" and "equity" are just as antiquated in "property" as they now are in "procedure." The domain of property awaits its Field Code, its Clark, and its "new federal rules." 
sleeping interests - than they now are. ${ }^{39}$ That is all the dreaded Torrens System does. What is this perilous "determination of title" which Professor Bordwell fears? It is not the expeditious, conclusive, judicial, initial registration-probably the best action to quiet title in the country-because he approves that. ${ }^{\circ}$ The danger, if any, must be in subsequent transfers after the title is cleared and the bookkeeping changed. Does this involve any "passing on the marketability" of a title? Clearly not-for two reasons. In the first place, title registration insofar as humanly possible gets rid of the whole "marketability" problem. That problem is caused by fears and threats of defects in title as much as by actual defects ${ }^{4 x}$-fears that the chaotic records have not been accurately searched, that some valid interest is not even exhibited in these records and has not been found by outside search. It is common knowledge that, however difficult the proof, most titles are actually good; it is the danger of the one chance out of a hundred which forces all the costly and dilatory procedure outlined above. Obviously title registration destroys, bag and baggage, these particular threats and dangers. In the second place, insofar as a tract index may still indicate a multiplicity of interests in a particular piece of land, there is no reason why the prospective purchaser should not still call in his skilled lawyer to tell him what the register page says. ${ }^{42}$ All the alleged unskilled public administrator has to do in operating the mechanics of the system is to see that the deeds presented to him are executed with the proper formalities-description of parties, description of land, signatures, acknowledgments, seals, and so forth, including whatever the state may

39 That few people, whatever the merits or demerits of their claims to protection, would be actually "injured" by this cutting off of sleeping interests is indicated by the relative rarity of claims against assurance funds under registration. Powell, op. cit. supra note 3 , at 223, I6r, I95.

${ }^{40}$ In any state the initial registration can be as conclusive as any action to quiet title or statute of limitations can be made in this country. The great need is, however, for something more than a good action to quiet title; it is for a system of keeping the books which will make fewer actions to quiet title necessary. Professor Bordwell writes (Bordwell, 488): "Once title is quieted there will be little trouble about its further marketability." For how long, if registration is not substituted for recordation? The recording system, operated under the gracious control of caveat emptor, offers no method of periodically posting the books and getting rid of stale claims. Any comparison of the conclusiveness of registration with the "conclusiveness" of the recording system is a comparison of strictly non-comparables; conclusiveness for all practical purposes and complete inconclusiveness belong to different realms of social fact.

${ }^{4 x}$ Threats of title defects, like threats of war, may be almost as costly and troublesome as the actual thing; preparation must be made for any eventuality.

$4^{2}$ Professor Bordwell recognizes this in his discussion of the tract index but he minimizes the possibility, by making the books conclusive, of getting rid of most of the roots of "marketability" trouble. 
require. ${ }^{43}$ This does not, in a day when even our own poor, benighted American public administrators are performing so many complex functions, seem a very exacting task; it is about as rudimentary a function as could be asked of a public land office. ${ }^{44}$

The charge that title registration is a "foreign" system is as groundless as it would be unpersuasive if it had grounds. Every element of registration-the action to quiet title, the tract index, the effort to make the records more conclusive, the statute of limitations, and the general zeal for efficiency-are all now at least of good native American stock, well represented among the flora and fauna of our various states. Sir Robert Torrens, who loaned his name as a battle-cry for an Anglo-Saxon combination of all these elements, was of course a foreigner. So what? So have been hundreds of other inventors and promoters whose technological improvements we have borrowed. No one is suggesting "totalitarian" means for the achievement of the demonstrably desirable end of registration; all that is being tried is the time-honored, democratic method of "education." 45 Surely it is no more "totalitarian" for a democratic state legislature to require, as several have required (with respect to land entered in "voluntary" registration systems) for more than forty years, that to be enforceable against a bona fide purchaser a title must be "registered" than it is for such a legislature to require that to be so enforceable a title must be "recorded." ${ }^{46}$ Nor does registration involve any un-American invasion of a domain where private business can effectively function. The choice here

${ }_{43}$ Such prophylactic activity by registrars could eliminate a tremendous amount of wasteful litigation about "formalities" and "delivery."

44 From the perspective solely of the governmental provision of information, title information is the most rudimentary kind of information which should be made readily accessible to prospective purchasers and planners. Imagine how much it would encourage both free enterprise and rational planning if there were some central, municipal bureau which could supply quickly and cheaply not only information about title but also information about taxes, public services, prices, age and condition of structures, public and private restrictions, population trends, and so forth. The saving in public expenditure by such consolidation and integration of activities might, furthermore, not be inconsiderable.

45 The suggestion made by many opponents of registration that there has been no great public hue and cry for it is pointless. How can the general public be expected to demand something of which it is ignorant and which has even been misrepresented to it? I know, for example, one able title lawyer, a man of reasonable public spirit, who does not hesitate to make ex cathedra judgments condemning registration, yet his comments indicate that he does not have the remotest conception of what the system involves. One function of the disinterested student should be to try to create a demand for new and improved social institutions. Cf. Iynd, Knowledge for What? (I939).

${ }^{46}$ Professor Bordwell well says (Bordwell, 478): "But the right of the owner of land to choose between an alphabetical index under the prevailing system and a tract index under registration hardly seems to be of the essence of liberty." 
is not, as General MacChesney poses it, between doing business with a private agency or a public agency. ${ }^{47}$ The question is not whether certain business will be left in private hands or transferred to the government, but whether an admittedly public function--the keeping of books about land transfers-shall be performed so badly as to make necessary an otherwise unnecessary private business. ${ }^{8}$ The logic of General MacChesney's position must drive him to the view that the public should not collect any title information about land, to a denial of the most rudimentary function which a public land agency can perform. It has long been recognized, however, that the necessities of cost and efficiency make the collecting of title information essentially a "monopoly" business and that the added necessity of even reasonable protection for purchasers makes it unquestionably a "public" business. It is simple common sense that what the government must do, it should be permitted to do well.

The problem of land transfer, insoluble by obsessive reiteration of ancient bromides about individualism or by making the eagle scream with far-fetched analogies, is rightly nothing more than a question of organizational efficiency and of cost and protection to the consumer. From such a perspective, despite General MacChesney's and Professor Bordwell's insistence that "it can't happen here," the day for title registration in this country is just beginning to dawn: it has no need of "resurrection"; it is far from dead; it is big with all the life of the swelling contemporary demands of millions of people for livable homes, in a livable environment, at an approachable price and of other millions for some kind of farm security; it may not "save" these millions for some far-flung millennium; but it is an indispensable, if perhaps minor, element in a comprehensive program for the rehabilitation of a substantial part of their lives.

47 Book review, op. cit. supra note 19.

${ }^{48}$ When General MacChesney writes, op. cit. supra note 19 , at I59, of the "vested interests" of the "public" and of "landowners" in the "recording system," his meaning escapes my grasp. 